$\mathbf{E}$. The trunk of the left spermatic vein and artery surrounded by the left

F. The aorta divided a little above the origin of the right spermatic artery, and about three inches above its division into the two common iliac arteries.

G. The vena cara.

H. Trunk of the right spermatic vein entering the vena cava.

I. Right ureter.

$\dot{K}$. The two cords of the great sympathetic nerve passing down along the front of the aorta.

I. Trunk of the inferior mesenteric artery, passing off from the aorta, and ecrered with a great plexus of nerves sent off from the left and right cords of the great sympathetic.

M. M. The two cords of the great sympathetie passing down below the bifurcation of the aorta to the poiut where they separate into the right and left hypogastrie nerves.

N. The right hypogastric nerve, with its artery injected, proceeding to the neck of the nterus, to terminate in the right hypogastric ganglion.

o. The left hypogastric nerve where it is entering the left hypogastric ganglion, and giving off branches to the left sub-peritoneal ganglion.

P. Hæmorrhoidal nerves accompanying the hæmorrhoital artery, and proceeding from the great plexus which surrounded the inferior mesenteric artery.

Q. The sacral nerves entering the whole outer surface of the hypogastric

R. The left hypogastric ganglion, with its arteries injected.

S. The nerves of the ragina.

T. Nerves with an injected artery proceeding from the upper part of the left hypogastric ganglion along the body of the uterus, and terminating in the left spermatic ganglion.

U. Continuation of these nerves and the branches which they give off to the sub-peritoneal plexuses.

V. The same nerves passing upward beneath the sub-peritoneal plexuses, and anastomosing freely with them.

W. The left spertuatic ganglion, in which the nerves and artery from the hypogastrio ganglion, and the branches of the left sub-peritoneal plexuses terminate, and from which the nerves of the fundus uteri are supplied.

$\mathrm{X}$. The left sub-peritoneal plexuses covering the body of the uterus.

Y. The left sub-peritoneal ganglion, with numerous branches of nerres extending between it and the left hypogastric nerve and ganglion.

Z. The left common iliac artery cut across and turned aside, that the lef hypogastric nerve and ganglion might be traced and exposed.

(To be continued.)

\section{TREATMENT OF SLOUGHING SORES BY CHLORINE.}

By THOMAS S. FLETCHER, EsQ, M.R.C.S.

AT the suggestion of the professor of surgery at the Queen's College, Birmingham, I beg to call the attention of the readers of THE LANCET to a simple and at the same time highly efficacious mode of treating slouching wounds by means of chlorine. The first case in which $I$ used this article as a curative agent fully illustrates how powerfully it possesses these properties.

A man, aged eighty-four, was in Angust last shot throngh the palm of the hand, and, in a few days, the wound becoming very offensive, each orifice was covered with large pads of tow, dipped in a weak solution of chlonide of lime (two drachms of the powder to a pint of cold water, ) and the dressing renewed about twice a day. The offensive odour was immediately destroyed, the wound became clean and healthy, the granulations sprung up with great rapidity, soon covering the ends of the fractured bones, and healing up the wound, and this without the use of any other remedy.

I have trusted to the sole use of chlorine in other cases with equal success, applying it not only where the wounds are become offensive, but in the earlier stages, where there was reason to apprehend there would be sloughing or offensive discharges. Various preparations of chlorine have long been used to remove the odour from wounds, and for this purpose they are applied over other dressings; but what $I$ here wish to recommend is that it should be used alone, and as a curative remedy. The rationale of its action may perhaps be explained in the following manner:- Portions of the wounded parts are preserred from sloughing by means of the antiseptic properties possessed by chlorine; granulations are to a very remarkable extent promoted-first, by the stimulating power of chlorine, from its increasing the activity of the small vessels on the surface of the wound, and secondly, by the peculiar property it has of keeping the wound clean, and thus enabling the plastic cells formed from the liquor sanguinis to have immediate contact with, and adhere to, active living substance, and so form new healthy tissue, instead of their being thrown off in the form of pus. If chlorine has the power of increasing the process of granulation, it must, as a natural consequence, have in an equal ratio the property of suppressing the suppuration. Lastly, the formation of those noxious gases and larvæ so detrimental to the parts themselves and injurious to the general health, is prevented by the chemical action of chlorine.

Poultices, ointments, and hot and cold water applications, do not possess the above properties; and if they promote, as I fear they do, what is most favourable to sloughing, heat and moisture, and the confinement of the noxious gases and discharges to the parts, they must in these respects have a tendency to do harm.

I trust that this suggestion may be the means of materially adding to the comfort of the wounded in the East, and effectually preventing those loathsome scenes amongst them painfully recorded in wany papers.

Bronsgrore, Nov. 1854.

\section{REPORT OF A CASE OF TRANSPOSITION OF THE VISCERA.}

By THOMAS CHAPLIN, EsQ., M.R.C.S. and L.S.A. BESIDENT MIEDICAL OFFICER TO THE BLOOMSBERX DISPENSARX.

Sopra H- died on the 8th of July, 1854, aged one year and ten months. The body was examined forty-eight hours after death. On opening the abdomen, the liver was found to be placed upon the left side, and, from being enormously enlarged, extended downwards as far as the crest of the ilium, whilst the small lobe crossed the abdomen and occupied nearly the whole of the right hypochondriac region. The large end of the stomach was on the right side, the pylorus and duodenum being on the left. The paucreas was placed to the right of the duodenum. The spleen, which was very large, was situated in the right hypochondriac region, and reached as low as the iliae fossa. The left kidney was lower than the right. The cecum was in the left iliac region; the sigmoid flexure in the right. On examining the chest, the heart was found with its apex pointing to the right side, and the aorta, which proceeded from the right ventricle, arching downwards towards the right side of the spine. The left lung had three lobes, the right lung only two.

The child had been delicate from its birth, and some time before its death had fallen into a very cachectic condition. The autopsy showed evidences of recent general peritonitis. Both lungs were partially emphysematous, and there were signs of rather severe bronchitis. The heart was large, and the pericardium roughened in sevcral spots by an old deposition of lymph.

Great Pussell-street, Dec. I854.

\section{de attirur}

OF THE PRACTICE OF

\section{MEDICINE AND SURGERY IN THE}

\section{HOSPITALS OF LONDON.}

Nulla est alia pro certo noscendi via, nisi quam plurimas et morborum et discectionum historias, tam alionm proprias, collectas habere et inter se comparare.-NorgagNi. De Sed. et Caus, BMorb. lib. 14. Procmium.

\section{ST. THOMAS'S AND UNIVERSITY COLLEGE HOSPITALS.}

TWO CASES OF STRANGULATED LTGUINAL HERNIA; OPERATION; OPENING OF THE SAO; RECOVERY.

(Under the care of Mr. Le Gros ClakK and Mr. QUaIN.)

Althovgr there is some difference of opinion amongst surgeons as to the propriety of opening the sac in the operation for strangulated hernia, we are confident that the peritoneal investment is never laid open, except the surgeon conscientiously thinks the measure necessary. But even when this necessity is most manifest, there may be some apprehension in the mind of the operator, who is apt to ask himself whether he is not, by laying bare the intestine, jeopardizing his patient's life?

Now, it must be evident to those who see a great many of these operations, that the opening of the sac, and even the decidedly dark colour of the bowel, are, to say the least of it, pretty often followed by favourable results. Of course, we are only here stating a general impression, and know full well that 